\title{
REVISITING TRADITIONAL, MODERN AND ISLAMIC VALUES WHEN ADDRESSING HAZE ISSUES
}

\author{
Shahino Mah Abdullah* \\ Muhammad Adha Shaleh**
}

\begin{abstract}
Almost every year, widespread forest fires from western Sumatra and southern Kalimantan in Indonesia have caused a series of transboundary hazes that have enshrouded parts of Southeast Asia. This disaster has jeopardised health, the economy, agriculture and biodiversity. It has also worsened climate conditions due to its large addition of global greenhouse gases (GHG) to the atmosphere. As a result, Indonesia has received great criticism from its neighbours. This disaster is mainly caused by the slash-and-burn methods used to clear land, claimed by many to be a local indigenous farming practice. However, instead of blaming the Indonesian authorities for their inefficient actions, other countries that benefit from Indonesia's resources should take responsibility and assist in addressing the issue by finding the root of the problem. A thorough understanding of this matter is necessary and must be initiated by revisiting and exploring local community welfare, culture, and traditional wisdom in order to address and prevent transboundary haze issues. This paper discusses the causes and results of transboundary haze and highlights the importance of traditional wisdom and Islamic teachings for the preservation of the environment (hifz al-bi'ah) and achieving sustainable development goals. It concludes with several policy recommendations for policymakers to consider as a means of preventing this issue from recurring in the future.
\end{abstract}

Keywords: haze, climate change, traditional culture, environmental wisdom, ethical values, sustainable development.

\section{Introduction}

Most climate scientists have unanimously agreed that the main cause of current global warming is human activity - 'anthropogenic climate change'. ${ }^{1}$ Globally, the emission of carbon dioxide $\left(\mathrm{CO}_{2}\right)$ is the most significant factor in this process, with this gas having the largest concentration in the earth's atmosphere compared to other greenhouse gases (GHG). This gas traps thermal infrared radiation, preventing it from escaping into outer space, and thereby becomes the main cause of global warming, leading to climate change. Despite the widely 
known causes of $\mathrm{CO}_{2}$ emissions, which stem from industry, transportation and energy production using carbon-based fuels ${ }^{2}$ the sum of agricultural activities, food production, land-use and forestry also made a large contribution of up to 29 percent (i.e. above one-fourth) of the total global GHG emissions. ${ }^{3,4}$

In this regard, the world needs sustainable resources management and development practices to curb climate issues. The transition from fossil fuels to renewable energies has taken place in developed nations, vigorously reducing their carbon footprints. ${ }^{5}$ Among their progressive measures has been the increasing of facilities for renewable energy, including solar farms, wind turbines, hydroelectric plants and electric vehicles. However, the GHG emissions that have been released by agricultural activities, food production, land-use and forestry are beyond the control of a single country. To date, the most frequent anthropogenic transboundary haze in the world related to these issues has taken place in Southeast Asia, caused by land-use changes, open burning, peat combustion, wildfires, and other farming activities. ${ }^{6}$

A series of some of the most serious hazes ${ }^{7}$ ever recorded took place in 1983, 1997, 2005, 2006, 2009, 2010, 2013, 2015 and 2016, and originated from largescale forest fires from western Sumatra and southern Kalimantan, Indonesia. ${ }^{8}$ These hazes brought adverse effects to both local communities and neighbouring countries concerning health, the economy, agriculture, and biodiversity. ${ }^{9}$ For instance, there were increases in respiratory mortality due to toxic airborne particles, ${ }^{10}$ jet crashes, ${ }^{11}$ ships collisions ${ }^{12}$ due to restricted visibility, reduction of crop growth rates due to limited solar radiation, ${ }^{13}$ and the extinction of endangered primates due to habitat $\operatorname{loss}^{14}$ in the aftermath of these hazes. Neighbouring countries like Malaysia ${ }^{15}$ and Singapore ${ }^{16}$ closed their schools in order to prevent exposing people to air pollution as well as to reduce carbon emissions from traffic. This paper aims to identify the root cause of the wildfires in Indonesia that have been responsible for these transboundary hazes around Southeast Asia and, at the same time, highlight several preventative measures to stop this issue recurring in the future. In this regard, we conclude with a set of policy recommendations taking into account the importance of local community welfare as well as the role of countries that benefit from Indonesian resources.

\section{Role of Ethical Values in Addressing the Anthropogenic Impact}

Transboundary haze caused by forest fires in Indonesia has been an annual problem due to the widespread use of the easiest and cheapest method to clear land, slashand-burn. This practice, reports claim, is a traditional farming method practised by the indigenous people of Indonesia. It is also used, however, by corporations 
for pulpwood and palm oil plantations. According to Herry Purnomo, a professor at Indonesia's Bogor Agricultural University and a scientist at the Center for International Forestry Research (CIFOR), there are two offenders: poor smallscale farmers attempting to expand their farmland, and scoundrel operators intent on clearing forests illegally for land acquisition. ${ }^{17} \mathrm{He}$ also highlighted influential patronage networks involving local Indonesian elites and individuals who are responsible for the burning which hinder the government's capacity to allocate economic resources efficiently.

For a long-term solution, fire prevention must be the priority rather than firefighting. There are several possible preventive measures for urgent implementation by the authorities. For instance, the elimination of market demand for illegal land for plantations could mitigate deforestation. The authorities must pledge mandatory requirements for companies to ensure fire prevention, while also enforcing strict fines and punishments for the lawbreakers. There is also a necessity for an anti-corruption body that can work against patronage networks to ensure efficient government bureaucracy. Last but not least, the authorities and stakeholders must develop and provide clear plans for landholders to manage their land sustainably. These measures will require crucial ethical values from every individual, regardless of their position in society. In this respect, the standardsetting action taking place in the field of bioethics is pivotal and indispensable. Most importantly, all people, including leaders and stakeholders, must follow and adopt the ethical benchmark outlined in the 'Universal Declaration on Bioethics and Human Rights' (UDBHR). ${ }^{18}$ This declaration, which was drafted by UNESCO in consultation with the Intergovernmental Bioethics Committee, can be used as a guideline for policymakers, while also enhancing laws and regulations in tropical countries.

Some of the main provisions of the UDBHR include cultural diversity and pluralism (Article 12), international cooperation (Article 13) and the promotion of health and social development for all people (Article 14). The declaration also highlights the importance of human beings in the protection of the environment (Article 17) and the establishment of an ethics committee to assess scientific developments and provide advice on ethical and legal problems in clinical settings (Article 19). In the context of the haze issue in Southeast Asia, these provisions could be the key points for policymakers to consider, to revisit and promote in terms of local pluralism, traditional wisdom and environmental ethics. In theory, local traditional wisdom encompasses indigenous, religious and cultural values in which core teachings are in line with sustainability. In the past, local Malay folk advice and abstentions, known as petua and pantang larang respectively, figuratively disseminated guidance, recommendations and prohibitions emphasising the purpose and reason of human actions. ${ }^{19}$ The 
messages this advice brought were not limited to the betterment of individuals and societal life, but also included the right manner of interaction between human and the environment. ${ }^{20}$

\section{Traditional and Modern approaches to Preserving the Environment}

It is noteworthy that traditional practices do not promote greed, which will eventually compromise its own goal. The new generation should learn this precious value wisely and appreciate the lesson it imparts. In the case of haze in Southeast Asia, the 'slash-and-burn' method adopted by irresponsible individuals, farmers and companies in clearing the land for various profitable purposes is contrary to the objective of the original traditional practice. The traditional practice did not aim at maximising profitable outcomes, but was intended to fulfil the needs of the local community for food through traditional sustainable farming and homes, amenities and boats using the felled wood, as well as widening the source of side income for the local people by making handicrafts from the leftover resources. Interestingly, even traditional food wrapping materials were completely based on leaves collected from shrubs and planted trees, such as dillenia suffruticosa, tectona grandis, hibiscus tiliaceus, banana, pandan, and coconut leaves, all of which are free from toxic compounds and allow the return of soil nutrients upon decomposition. ${ }^{21}$

Today's farming activities are more than just for subsistence. Large-scale farming and plantation sectors keep expanding and involve deforestation. Indonesia and Malaysia, for example, are the largest palm oil producers and exporters in the world. As both countries practice a monoculture system for their plantations, they will compromise the earth nutrients and soil strength. A monoculture technique will potentially cause a drastic loss of nutrients from the earth and weaken the soil's ability to support healthy plant growth in the future. However, the Malaysian government has started several initiatives to ensure a sustainable palm oil plantation system. By 1 January 2020, the entire production and supply chain in Malaysia must be certified under the Malaysian Sustainable Palm Oil (MSPO) Certification Scheme. This is aimed at achieving a balance between economic development, social development and the protection of the environment through the implementation of the MSPO standards (MS 2530 series of standards).

The main principles of MSPO certification emphasise the importance of: (1) management commitment and responsibility, (2) transparency, (3) compliance to legal requirements, (4) social responsibility, health, safety and employment conditions, (5) environment, natural resources, biodiversity and ecosystem, 
(6) best practices, and (7) development of new planting. The second principle, transparency, will certainly benefit producers, traders, consumers, the public and regulatory bodies. Most importantly, the third principle promotes energy efficiency, use of renewable energy, reduction of pollution and emission, natural water resources, protection of endangered species, high biodiversity, and zero burning practices. The Malaysian sustainable palm oil plantation strategy could actually be a model for those countries that plan to carry on with the palm oil industry in the long term. Systematic enforcement by regulators to curb wildfires, including new innovative ideas that promote environmental preservation (hifz al$b i$ ' $a h$ ), is necessary in order to face future challenges in actualising a sustainable practice in the palm oil industry overall.

\section{Preservation of the Environment from an Islamic Perspective}

The local communities in the Malay Archipelago mostly adhere to Islam, which has become their way of life, shaping their traditional culture and finally marking their identity. Islamic teachings have spread throughout the Malay World and are well accepted by the people. Islamic teachings address the human-earth relationship through a set of principles, namely tawhid (Divine Oneness), khalifah (vicegerency of man), and amanah (trusteeship). ${ }^{22}$ Firstly, the principle of tawhid is manifested in the unity of God's creation, which includes men, women and the whole universe that exists in balance. It means that human beings are part of a natural equilibrium that must not be disturbed. Secondly, the principle of khalifah implies that humanity holds a position of power, trust and responsibility to build the earth. It also means that humanity has a responsibility to safeguard the rights of fellow humans and other inhabitants of the earth. Thirdly, the principle of amanah, as an integral part of the faith of a Muslim, highlights the entrusted role of humanity as custodian on the earth. While the most important of all amanat is justice (' $a d l$ ), the doing of good (ihsan) towards fellow humans and the natural environment is also important. Further, these principles lead to the concept of $i$ 'mar al-ard (building of the earth) that encourages human progress in developing the earth without compromising environmental well-being.

For this reason, the practical approach to leveraging natural resources must be set within a sustainable context. In terms of the haze issue in Southeast Asia, the slash-and-burn technique should be banned to address the spread of wildfires. An environmentally friendly zero burning technique must adopted for land clearing instead, as such a technique has been proven to save a lot of valuable forest resources in Malaysia. Zero burning involves the extraction of saleable and usable timber to be utilised as temporary bridges, to strengthen road 
foundations, construct drains, create natural streams that avoid rapid drying, to aid soil compaction to avoid shrinkage, to construct proper road systems to ensure sufficient access, to construct well-planned terraces strengthened by debris, and to establishment a legum cover crop to enhance the decomposition of that debris. ${ }^{23}$ This method certainly ensures all assets in the forest will be fully utilised, well-managed and used to promote efficient consumption of resources, which is in line with Islamic teachings to avoid wastage and pollution (fasad).

The role of human beings in managing natural resources must be made clear. They are not created to be consumers but vicegerents of the earth (khalifah). As stated, in Islam a vicegerent encompasses important aspects of trusteeship (amanah), such as justice ('adl) and the doing of good (ihsan) towards fellow humans and the natural environment, in order to keep the ecosystem in balance (mizan). In this regard, it is of considerable importance to include a holistic framework that integrates religious aspects into a conceptual model of the built environment by taking a maqasid al-shari 'ah (higher objectives of Islamic law) approach as a guide. ${ }^{24}$ The maqasid highlight the importance of preserving five essential goals: faith (din), life (nafs), progeny (nasl), intellect ('aql), and property $(\mathrm{mal})$. The advancement in maqasidi discourse has included the significance of environmental preservation (hifz al-bi 'ah). Further, this particular objective is in line with the Qur'anic principle of $i$ ' mar al-ard (building the earth) that encourages human progress in developing the earth without compromising environmental well-being. ${ }^{25}$

\section{Issuance of Fatwa to Protect the Environment and Ecosystem}

According to Mohammad Hashim Kamali, Muslim jurists have stressed the importance of reality-based Islamic jurisprudence (fiqh al-waqi') that is suitable to our time and place. Therefore, shariah-oriented policy (siyasah shar'iyyah) must be strengthen as currently it is mainly concerned with politics and the management of community affairs. Siyasah is characteristically concerned with real-life issues and reads the specific rules of figh in light of the overall objectives and purposes of shariah. Kamali has added that fiqh al-waqi' must pay attention to rapid advances in scientific progress, especially in matters of concern to fatwa that require specialised knowledge. Issuance of any fatwa of concern to issues of a specialised nature must have adequate input from an expert, with the mufti being well-informed about the required expert knowledge. ${ }^{26}$ Therefore, Islamic leaders and clerics are recommended to work together with environmental organisations, whether from governmental or non-governmental organisations, to protect the ecosystem. The key indicator to the issuance of correct fatwa is 
that it has a significant impact on existing law, since most people, especially in majority Muslim communities in Southeast Asia, are more impressed with the calls of religious messages.

Interestingly, this approach has prevailed in recent years with the issuance of the first fatwa by the Indonesian Council of Ulama aimed at preserving the ecosystem by declaring it forbidden (haram) to hunt or illegally trade in endangered species. As the country with the largest Muslim population in the world, Indonesia's top Muslim clerical body has issued this fatwa that will apply to both individuals and government institutions. According to Hayu Prabowo, chair of the Council of Ulama's environment and natural resources body, "This fatwa is issued to give an explanation, as well as guidance, to all Muslims in Indonesia on the shariah law perspective on issues related to animal conservation." ${ }^{27}$ The fatwa was originally inspired by a field trip to Sumatra for Muslim leaders in September 2013. The visit was co-organised by Indonesia's Universitas Nasional (UNAS), WWF-Indonesia, and the Alliance of Religions and Conservation from the UK, with additional consultation offered by Indonesia's Ministry of Forestry and HarimauKita (the Indonesian Tiger Conservation Forum). The fatwa that was officially issued in 2014 was not limited to the protection of animals, but reached further, as far as the oil palm business that endangers wildlife when companies clear the forest by means of setting a devastating wildfire. In this case, even though the main aim of the fatwa is to protect endangered wildlife, it can simultaneously be a useful instrument to restrict such wrongdoing and minimise the haze issue in Indonesia.

Malaysia became the second country to implement a similar approach in the following year, 2015, with the issuance of a fatwa against wildlife poaching. This fatwa, which is likely the first of its kind issued by a Malaysian state, Terengganu, recognises that illegal hunting is forbidden (haram) ${ }^{28}$ It calls upon Muslims to protect Allah's creation and forbids them from hunting any species to extinction. The state Mufti Department worked together with experts from the state's Department of Wildlife and National Parks (PERHILITAN), Universiti Malaysia Terengganu (UMT), and James Cook University, Australia. ${ }^{29}$ Terengganu mufti Datuk Dr Zulkifly Muda said, "I urge Muslims to stop all forms of hunting in general to prevent species extinction and to safeguard our environment," at a fatwa and falak seminar organised by Terengganu's Mufti Department, which was attended by over 500 local people. The issuance of this fatwa will play a pivotal role in Terengganu since many of those who are involved in poaching belong to communities that are predominantly made up of practicing Muslims and who are not aware that the Malayan tiger and sambar deer are facing extinction. ${ }^{30}$ Malayan tigers, for example, are hunted for their medicinal properties and in retaliation for killing livestock. Even though this fatwa will not instantly stop poaching, it is 
expected to create peer pressure among poachers to stop killing those animals. Experts hope that other Malaysian states will follow Terengganu's example and issue similar fatwas against poaching since it is a national problem. At the moment, this approach will play only a relatively small role in eradicating the haze problem since the wildfires in Terengganu are not due to the wrongdoing of oil palm companies or irresponsible individuals but to the El Nino phenomena. ${ }^{31}$

Not long after the issuance of Terengganu's fatwa on illegal hunting, the Perlis Fatwa Committee came up with a fatwa on environmental pollution in early 2016. Perlis, Malaysia's smallest state, located in the north, is proactive in addressing the religious and environmental issues that have stirred the country. State Mufti, Mohd Asri Zainul Abidin, said, "The act of polluting the environment which directly affects nature's ecosystems causing harm to living things is in conflict with the teachings of Islam." He added, "Islam is a religion that calls upon its followers to preserve the wellbeing of human life and the universe, and not perform harmful acts." The fatwa issued by the Committee seems to be generalised as it mentions that "any act that pollutes the environment and affects direct physical harm to humans, animals and plants is forbidden, except if there is a greater interest (maslahah) or in order to avoid a clear harm (mafsadah)." Asri specifically pointed out that the bauxite mining case in Kuantan threatens to pollute rivers and burn the forests. ${ }^{32} \mathrm{He}$ reminds the public, especially Muslims, that Islam is a religion that upholds the well-being of human life and nature and that the purpose of shariah (maqasid al-shari'ah) is to uphold the best interests (mafsadah) of humanity. With the issuance of this fatwa, including brief explanation by the Muftis, Malaysia has, through its state religious bodies, made clear that the violation of the ecosystem is totally prohibited and that the protection of the environment (hifz al-bi'ah) is a priority in order to preserve the well-being of the people and their surroundings.

The issuance of fatwas that supplement existing law is not the only available approach and measure to curb environmental issues. By law, fatwas have no legal force, but are rather aimed at encouraging devout Muslims to take a certain course of action. Therefore, practical enforcement to prevent and curb widespread environmental pollution should be an obligatory measure in the context of stopping wildfires that cause haze. This can be seen from a recent fatwa from Indonesia's Ulama Council. Issued in late 2016, it forbade the intentional starting of fires in the forest or on plantation land on the grounds that the practice goes against Islamic law. ${ }^{33}$ Dr Huzaemah Tahido Yanggo, who now leads the council, said, "The fatwa specifically addresses the intentional burning of forest and plantation land, we are not referring to accidental fires." ${ }^{34}$ She added, "The Qur'an states that we are not allowed to harm the environment, and forest burning causes damage not only to the environment but also to people's health." Siti 
Nurbaya Bakar, Indonesia's Environment and Forestry Minister, welcomed the fatwa and said, "The most important follow-up is communicating it to the public," stating that she hoped Islamic preachers would spread the message to local communities. During the most recent fire disaster in Indonesia, the nation's National Disaster Management Agency (BNPB) deployed about 3,500 firefighters, while President Joko Widodo himself ordered the deployment of more than 10,000 police and soldiers and water-bombing planes to contain the fire. ${ }^{35}$ The Indonesian government also filed a number of lawsuits against plantation firms, with some of the companies being shut down permanently after having their licences revoked.

More measures can be added to strengthen government policy and action designed to curb pollution due to illegal fire burning. Although the issuance of fatwas is clearly one, at the same time other preventative measures can be adopted, such as strengthening anti-corruption bodies, increasing forestland conservation, and eliminating patronage networks and market demand. The latter in particular will play a vital role in ensuring preventive action is really effective. Stricter enforcement actions, like filing lawsuits, revoking licences, and seizing land, are also necessary to prevent such disasters from reoccurring. A new policy that will favour small farmers and improve company activities must be developed so that the next plantation cycle will be more sustainable. At the same time, investors are encouraged to choose value-based investments (VBI) as these look at the environmental and social impact of a company's actions, products and leaders. Moreover, VBIs make the protection of the environment a core aim of running a business. VBIs are currently being studied and developed further to strengthen their presence in the Islamic financial sector and put them in line with the objectives of Shariah.

\section{Conclusions and Recommendations}

The above examples include traditional ways of life and religious principles that contain a lot of wisdom worth sharing between the communities and peoples of the world. The promotion of traditional wisdom, which includes cultural and religious aspects, could encourage local people to manage their surrounding environment in the most sustainable way while also maintaining their original identity. It is of great importance for people to inculcate a sense of belonging, especially within the land in which they reside, as an aid to environmental preservation. Conscientious restoration works are also necessary to fill in subtle gaps in their environmental wisdom as this has gone through the long process of inheritance across many 
generations. Within this context, the role of the international ethics committee and local scholars must be as a crucial guide to help indigenous communities address ethical and legal issues. At the same time, it is necessary to consider the 'sustainable community development' approach when addressing environmental and societal related issues. ${ }^{36}$ Indeed, this is an important component to ensure sustainability in community survival and development, since those who are poor and hungry will often destroy their immediate environment to survive, as stated in the Brundtland Report. ${ }^{37}$

The modern sustainable touch through smart technological advancement would also be beneficial to rejuvenate traditional foundations as such an approach is more capable of attracting the interest of new generations. Reinvigorated traditional practices that originate with local cultures will always find room for acceptance, making it much easier to implement and achieve global sustainable development. Therefore, it is important to revisit, support, and promote local cultures when addressing climate issues such as the human-made transboundary haze of Southeast Asia. In achieving this target, it is highly recommended to synthesise the current ethical model of 'sustainable community development' with the traditional environmental wisdom of local people, as well as with Islamic teachings on the role of humanity in preserving the environment.

Serious efforts to curb transboundary haze have already successfully reduced the number and size of wildfires as of 2017. However, we should not be complacent. Haze always occurs unexpectedly and might be repeated if current efforts are inconsistent, compromising the future environment. Therefore, several key solutions are needed to ensure all people unite in addressing this same issue. The following are several recommendations to mitigate environmental issues involving transboundary haze:

- A multidisciplinary collaboration, including representatives from the humanities, anthropology, sociology, and science, together with religious institutions, would offer a holistic approach towards sustainable resource management.

- Empower local communities in natural resource management, with a focus on their traditional wisdom, as this is known to promote sustainable environmental protection.

- Encourage religious experts to engage and communicate with local communities, sharing important messages regarding the environment and its ecosystem.

- Provide clear plans for how landholders and small farmers can manage their land sustainably. Malaysia, for example, has developed sustainable 
palm oil plantation techniques to protect the environment. This plan should also include the protection of community welfare so that local people will find it easy and realistic to implement.

- Develop a strict rule of law as a reminder to all people and companies. Punishment can be a lesson to prevent incidents from reoccurring.

- Encourage people, companies, and nations to invest in environmentally friendly businesses. Additionally, empower value-based investment by inculcating it with Islamic values. The latter could be a medium to filter out investments that involve illegal or unethical activities.

\section{Notes}

This article was written as the result of the authors' participation in the Expert Group Consultation meeting for the UNESCO project, 'Addressing Haze through Bioethics and Sustainability Science'. The meeting was held at the Institute of Islamic Understanding Malaysia (IKIM) on 18 September 2017.

* Shahino Mah Abdullah is a Research Fellow at the International Institute of Advanced Islamic Studies (IAIS) Malaysia. He can be contacted at shahino@, iais.org.my.

* * Muhammad Adha Shaleh is a Research Fellow at the International Institute of Advanced Islamic Studies (IAIS) Malaysia. He can be contacted at adha@iais. org.my.

1. John Cook, Naomi Oreskes, Peter T Doran, et. al. "Consensus on Consensus: A Synthesis of Consensus Estimates on Human-caused Global Warming", Environmental Research Letters, vol. 11 (2016), 048002.

2. Global Greenhouse Gas Emissions Data, U.S. Environmental Protection Agency.

3. Sylvia H. Vetter, "Greenhouse Gas Emissions From Agricultural Food Production to Supply Indian Diets: Implications For Climate Change Mitigation," Agriculture, Ecosystems and Environment, 237 (2017), 234-41.

4. Sonja J. Vermeulen, "Climate Change and Food Systems," Annual Review of Environment and Resources, vol. 37 (2012), 195-222.

5. Payam Nejat, Fatemeh Jomehzadeh, Mohammad Mahdi Taheri, et. al. A Global Review of Energy Consumption, $\mathrm{CO}_{2}$ Emissions and Policy in the Residential Sector (With an Overview of the Top Ten $\mathrm{Co}_{2}$ Emitting Countries), Renewable And Sustainable Energy Reviews, vol. 43 (2015), 843-62.

6. Tim Forsyth, Public Concerns About Transboundary Haze: A Comparison of Indonesia, Singapore, and Malaysia, Global Environmental Change, vol. 25 (2014), 76-86.

7. Helena Varkkey, The Haze Problem in Southeast Asia: Palm Oil and Patronage, (Oxford: Routledge, 2015).

8. Sinan A. Abood, Janice Ser Huay Lee, Zuzana Burivalova, et. al., Relative 
Contributions of the Logging, Fiber, Oil Palm, and Mining Industries to Forest Loss in Indonesia, Conservation Letters, vol. 8, issue 1, (2015), 58-67.

9. Fay H. Johnston, Sarah B. Henderson, Yang Chen, et al, Estimated Global Mortality Attributable to Smoke from Landscape Fires, Environmental Health Perspectives, vol. 120, no. 5 (2012), 695-701.

10. Shannon N Koplitz, Loretta J Mickley, Miriam E Marlier, et. al., Public Health Impacts of the Severe Haze in Equatorial Asia in September-October 2015: Demonstration of A New Framework for Informing Fire Management Strategies to Reduce Downwind Smoke Exposure, Environmental Research Letters 11: 9 (2016), 094023

11. Robert Cribb, "More Smoke Than Fire: The 1997 Haze Crisis and Other Environmental Issues in Indonesia" in Ecological Change in Southeast Asia, (Centre for Southeast Asian, Åbo Akademi University, 1998), 1-13.

12. C. Y. JIM, The Forest Fires in Indonesia 1997-1998: Possible Causes and Pervasive Consequences, Geography, vol. 84, no. 3 (1999), 251-60.

13. Tang Yanhong, Kachi Naoki, Furukawa Akio, and Muhamad Awang, Light Reduction by Regional Haze and Its Effect on Simulated Leaf Photosynthesis in A Tropical Forest of Malaysia, Forest Ecology and Management, vol. 89, no. 1-3, (1996), 205-11.

14. Catherine M. Yule, Loss of Biodiversity and Ecosystem Functioning in IndoMalayan Peat Swamp Forests, Biodiversity and Conservation, vol. 19, no. 2, (2010), 393-409.

15. Rafia Afroz, Mohd Nasir Hassan, and Noor Akma Ibrahim, Review of Air Pollution and Health Impacts in Malaysia, Environmental Research, vol. 92, no. 2, (2003), 71-7.

16. Djamil Yudha, Lee Wen-Chien, Tien Dat Pham, Kuwata Mikinori, Large-Scale Weather Dynamics During the 2015 Haze Event in Singapore, $19^{\text {th }}$ EGU General Assembly, EGU2017, Proceedings from the Conference held 23-28 April, 2017 in Vienna, Austria, 14180.

17. Oliver Balch, Indonesia's Forest Fires: Everything You Need to Know, The Guardian, 11 Novermber 2015.

18. Universal Declaration on Bioethics and Human Rights, Records of the UNESCO General Conference, $33^{\text {rd }}$ Session, Vol. 1, Paris (2005), 74-80.

19. Husni Thamrin, Kearifan Lokal dalam Pelestarian Lingkungan (The Local Wisdom in Environmental Sustainable), Kutubkhanah, vol. 16, no. 1, (2013), 46-59.

20. Tenas Effendy, Tunjuk Ajar dalam Pantun Melayu (Yogyakarta: Adicita Karya Nusa, 2004).

21. Normiadilah Adnan, Noriah Othman, The Relationship between Plants and the Malay Culture, Procedia - Social and Behavioral Sciences, vol. 42, (2012), 231 41.

22. Mohammad Hashim Kamali, Environmental Care in Islam: A Quranic Perspective, Islam and Civilisational Renewal, vol. 3, no.2, (2012), 261-83.

23. M. Mohd Noor, Zero Burning Techniques in Oil Palm Cultivation: an Economic Perspective, Oil Palm Industry Economic Journal, vol.3, no.1, (2003), 16-24.

24. Azila Ahmad Sarkawi, Alias Abdullah, Zaleha Kamaruddin, Nurul Aida Salim, and Norimah Md Dali, A Survey on the Understanding of Maqasid al-Shari'ah 
among Local Authorities in Malaysia in the Pursuit of Urban Sustainability, International Conference on Maqasid al-Shari'ah in Public Policy and Governance, at International Institute of Advanced Islamic Studies (IAIS) Malaysia on 15 \& 16 June 2015.

25. Mohammad Hashim Kamali, The Middle Path of Moderation in Islam: The Qur'anic Principle of Wasatiyyah, (Oxford: Oxford University Press, 2015).

26. Mohammad Hashim Kamali, What is Fiqh al-Waqi?, Bulletin on Islam and Contemporary Issues, IAIS Malaysia, no. 39 (2017), 1-4.

27. Bryan Christy, First Ever Fatwa Issued Against Wildlife Trafficking, National Geographic, 5 March 2014.

28. Adrian David, Terengganu First to Issue Fatwa Against Wildlife Poaching, New Straits Times, 30 November 2015.

29. Shreya Dasgupta, Malaysian State Issues 'Fatwa' Against Wildlife Poaching, Mongabay, 14 December 2015.

30. Jani Actman, Muslim Council Issues Fatwa Against Poaching, National Geographic, 16 December 2015.

31. Adrian David, Terengganu Firemen Battle Forest and Peat Fires Caused by El Nino, New Straits Times, 1 May 2016.

32. Rashvinjeet S. Bedi, Perlis Issues a Fatwa on Environmental Pollution, The Star, 1 March 2016.

33. Berndatte Christina Munthe, Kanupriya Kapoor, and Nick Macfie, Indonesian Islamic Council Issues Fatwa on Forest Fires, Reuters, 14 September 2016.

34. Francis Chan, Indonesian Islamic Council Issues Fatwa Against Forest-Burning, The Straits Times, 13 September 2016.

35. Sarah Porter, Can Indonesia's Forest Fires be Put Out for Good?, BBC News, 14 March 2016.

36. Mark Roseland, Sustainable Community Development: Integrating Environmental, Economic, And Social Objectives, Progress in Planning, vol. 54, no. 2, (2000), 73-132.

37. Brundtland Commission, Our Common Future, (Oxford: Oxford University Press, 1987). 